\title{
Kontrol Terhadap Tingkah Laku yang Dipersepsikan Sebagai Determinan Pembelian Makam Mewah
}

\author{
Masni Erika Firmiana ${ }^{1}$, Siti Rahmawati ${ }^{2}$, Rochimah Imawati ${ }^{3}$ \\ 1,2,3 Program Studi Psikologi, Fakultas Psikologi dan Pendidikan, Unievrsitas Al Azhar Indonesia, Kompleks \\ Masjid Agung Al Azhar, Jl. Sisingamangaraja Kebayoran Baru, Jakarta Selatan, 12110
}

Penulis untuk Korespondensi/E-mail: masni.erika@uai.ac.id

\begin{abstract}
Abstrak - Penelitian ini bertujuan untuk memprediksi tingkah laku membeli pemakaman mewah, di tengah situasi makin banyaknya masyarakat yang berada di status sosial ekonomi yang rendah, ditambah sudah keluarnya fatwa haram dari MUI. Prediksi ini diukur menggunakan Teori Planned Behavior dari Acjzen (1975), dengan metode kuantitatif. Alat pengumpul data adalah skala intensi dari Acjzen, dan sampel sebanyak 80 (delapan puluh) orang anggota majlis taklim. Hasilnya menunjukkan bahwa semua faktor yang dijelaskan oleh IV memiliki pengaruh sebesar 67.6\% terhadap DV, dan sisanya dipengaruhi oleh faktor lain yang tidak diteliti oleh penelitian ini. Ini berarti bahwa faktor sikap, norma subjektif, dan kontrol terhadap perilaku yang dipersepsikan memiliki pengaruh sebesar 67.6 \% terhadap tingkah laku membeli pemakaman mewah. Faktor yang memiliki pengaruh paling signifikan adalah kontrol terhadap tingkah laku yang dipersepsikan. Penelitian selanjutnya sebaiknya menggunakan sampel dengan jumlah yang lebih besar, dan lebih bervariasi (tidak hanya anggota majlis taklim). Selain jumlah sampel yang lebih besar perlu dipertimbangkan untuk melakukan riset kolaborasi dengan bidang ilmu lain, seperti ekonomi. Dengan jumlah sampel yang lebih besar dan cakupan area yang lebih besar, MUI dapat mempertimbangkan hasil riset ini sebagai data pendukung untuk mengeluarkan fatwa terkait fenomena ini.
\end{abstract}

Kata Kunci - Pemakaman, Niat, Sikap Mewah

Abstract - This study aims to predict the behavior of buying a luxurious funeral, amid the situation of the increasing number of people who are in low socioeconomic status, plus the release of fatwa haram from MUI. This prediction is measured using Planned Behavior Theory of Acjzen (1975), with quantitative methods. The data collection tool is the intensity scale of Acjzen, and a sample of 80 (eighty) members of majlis taklim. The results show that all the factors described by IV have an influence of $67.6 \%$ on DV, and the remainder are influenced by other factors not investigated by this study. This means that attitude factors, subjective norms, and control over perceived behavior have an effect of $67.6 \%$ on the behavior of luxury funeral purchase. The most significant factor is the control of perceived behavior. Subsequent studies should use samples with larger numbers, and more varied (not just majlis taklim members). In addition to the larger number of samples it is necessary to consider collaborative research with other disciplines, such as economics. With a larger sample size and greater area coverage, the MUI may consider the results of this research as supporting data for issuing fatwas related to this phenomenon.

Keywords - lavish funeral, intention, attitude

\section{PENDAHULUAN}

$\mathrm{D}$ alam beberapa tahun terakhir, peminat pembeli pemakaman mewah meningkat. Hal ini disampaikan oleh pengembang pemakaman mewah San Diego Hills. Pada trimester pertama tahun 2012 saja, pemakaman seharga ratusan juta sudah terjual 7 (tujuh) kavling [1]
Selain San Diego Hills, saat ini, setidaknya ada 2 (dua) pengembang lain yang memiliki kegiatan usaha pemakaman berharga tinggi ini dan berlokasi di sekitar Jakarta, yaitu Taman Kenangan Lestari Memorial Park, dan Al Azhar Memorial Garden. Menurut pihak pengembang, kecenderungan peningkatan ini terjadi sejak wilayah DKI Jakarta semakin sering mengalami banjir, dan salah satu 
wilayah yang terendam banjir adalah Tempat Pemakaman Umum (TPU) [1]. Selain itu, hal yang turut berperan adalah penggusuran yang kerap terjadi di beberapa wilayah di Jakarta, termasuk terhadap TPU. Hal lain yang juga turut berperan adalah tingginya pungli oleh oknum Dinas Pemakaman. Kecenderungan untuk berprilaku membeli pemakaman mewah ini dalam psikologi dikenal dengan istilah intensi (Ajzen, 1988).

Di tengah kondisi perekonomian Indonesia yang kadang tidak menentu, harga-harga yang cenderung tidak stabil, namun ternyata sebagian anggota masyarakat tetap memiliki intensi (kecenderungan berprilaku) membeli suatu produk jasa dengan harga yang relatif tinggi. Satu lobang makam di pemakaman mewah tersebut dapat mencapai 17 juta rupiah dan biaya tambahan untuk pemakaman sekitar 8 (delapan) juta rupiah. Harga tersebut termasuk tinggi jika dibandingkan dengan UMP DKI Jakarta 2014 sebesar Rp 2.200.000,- (kurang dari 1/10 harga makam), dan pendapatan per kapita Indonesia yang hanya US\$3.716 atau sekitar Rp 2.787.000/bulan [2] [3] [4].

Sebagian orang memandang tidak perlu membeli pemakaman mewah tersebut karena yang lebih penting adalah "kehidupan sesudahnya"; namun sebagian lainnya memandang itu suatu yang perlu untuk menunjukkan status sosial [5]. Hampir semua dari warga masyarakat tersebut (baik yang memandang perlu, maupun tidak), memiliki pendapat seperti itu karena pemahaman yang ditanamkan oleh orang tuanya sejak kecil. Dalam psikologi, terutama kajian intensi, hal ini diistilahkan dengan attitude toward the behavior. Menurut Ajzen [6], attitude (sikap) adalah evaluasi individu secara positif atau negatif terhadap benda, orang, institusi, kejadian, perilaku atau minat tertentu. Dalam riset ini, akan dikaitkan dengan sikap terhadap pemakaman mewah.

Pemakaman mewah yang dimaksud menyediakan layanan untuk semua agama yang ada di Indonesia (kecuali Al Azhar Memorial Garden yang khusus untuk muslim). Layanan yang dimaksud di sini adalah kompleks pemakaman yang dibangun dengan indah, sehingga jauh dari kesan seram yang selama ini melekat pada kompleks pemakaman [7] [8]. Di Al Azhar Memorial Garden, dengan harga paling murah (paket 10 orang) Rp 17.000.000 hingga Rp 180.000.000/orang. Pengembang lain menrapkan harga yang lebih tinggi. Berbagai macam fasilitas dan layanan berkelas disediakan oleh pengelola bagi keluarga yang melakukan ziarah, seperti rumah ibadah yang bagus dan megah, hotel, restoran Italia, kolam renang, dan danau buatan. Selain itu juga lokasi yang berbukit dan hijau, sangat menyenangkan untuk berjalan kaki, jogging (tersedia jogging track), dan bersepeda. Karena tempat yang indah dan jauh dari kesan seram, tak jarang lokasi pemakaman mewah ini juga digunakan untuk pemotretan foto pre wedding.

Saat ini, pemakaman mewah ini terlihat seperti menjadi sebuah gaya hidup. Tidak sedikit warga masyarakat yang berminat untuk memiliki, sehingga pemerintah memandang perlu untuk menyediakan lahan khusus untuk TPU yang mahal ini. Hal ini terlihat dari bahkan pemerintah kabupaten /pemerintah kota pun sudah menyediakan lahan yang cukup luas untuk pemakaman dengan layanan maksimal [9] [10].

Peneliti sudah melakukan wawancara awal dengan sejumlah anggota masyarakat yang ditemui secara accidental di beberapa tempat, hasilnya ditemukan pendapat yang beragam. Sebagian menunjukkan sejalan dengan Firmiana dkk [5], yaitu menganggap tidak perlu; sementara sebagian lagi justru berpendapat sebaliknya. Pertimbangan mereka adalah tidak ingin merepotkan keluarga saat dirinya meninggal, juga saat merawat makamnya. Biaya yang mahal tidak menjadi masalah, karena dananya bisa diusahakan dengan bekerja keras mulai dari sekarang. Bahkan sebagian dari yang menyiapkan makam mewah untuk diri sendiri, juga menyiapkan untuk pasangan, orang tua, saudara, serta anakanaknya sekaligus.

Di sisi lain, pada awal tahun 2014, Majelis Ulama Indonesia (MUI) mengeluarkan fatwa haram untuk pemakaman mewah masyarakat muslim [11]. Dasar fatwa tersebut adalah karena kompleks pemakaman mewah menawarkan berbagai fasilitas pendukung yang dinilai tabdzir dan israf. Definisi tabdzir adalah menggunakan harta untuk sesuatu yang siasia dan tidak bermanfaat menurut ketentuan syar'i ataupun kebiasan umum di masyarakat. Sementara israf adalah tindakan yang berlebih-lebihan, yaitu penggunaan lahan melebihi kebutuhan pemakaman [5].

Meski sudah ada fatwa tersebut, sepertinya tidak mengurangi minat calon pembeli. Salah satu pihak pengembang menyatakan, salah satu dari tiga area pemakaman khusus untuk umat Islam yang mereka sediakan sudah habis terjual per tanggal 2 September 2014 [12]. Ini berarti sesudah fatwa 
tersebut dikeluarkan oleh MUI, transaksi pembelian blok makam mewah untuk kaum muslim tersebut tetap berjalan. Tampaknya ini sejalan dengan temuan Salehudin dan Luthfi bahwa halal tidaknya suatu produk barang dan jasa bukan menjadi suatu acuan bagi masyarakat muslim di Indonesia saat akan membeli produk barang dan jasa; serta tidak akan berpengaruh pada pembatalan pembelian setelah diketahui produk yang dimaksud belum memiliki sertifikat halal [13].

Berdasar beberapa hal tersebut, tim peneliti ingin melakukan penelitian terkait intensi [6]. Intensi dilakukan untuk memprediksi perilaku manusia. Intensi dalam masyarakat dalam penelitian ini akan dilihat dari faktor-faktor : sikap, subjective norm, dan kontrol terhadap tingkahlaku yang dipersepsikan, seperti yang disampaikan oleh Ajzen [6] dalam Theory of Planned Behavior (TPB). Berdasar teori tersebut, akan dilihat apakah 3 (tiga) faktor tersebut membuat anggota masyarakat akan membeli atau tidak membeli makam mewah? dari 3 (tiga) faktor tersebut, faktor manakah yang paling berpengaruh?

Penelitian ini bertujuan untuk menjelaskan perilaku konsumen apakah akan membeli atau tidak membeli pemakaman mewah; jika membeli, aspek apa yang paling menentukan dalam keputusan melakukan pembelian?

\section{Manfaat Penelitian}

Hasil riset ini diharapkan dapat menjelaskan fenomena pemakaman mewah pada masyarakat muslim Jabodetabek. Selain itu, riset ini dapat memberikan deskripsi kepada pengelola ataupun pengembang pemakaman mengenai aspek yang paling berperan dalam keputusan seseorang untuk membeli pemakaman mewah. Berdasar riset ini pengembang dapat mengembangkan strategi pemasaran produknya. Bagi MUI, hasil riset dapat dimanfaatkan untuk kebijakan-kebijakan selanjutnya, misal, sesudah dikeluarkan fatwa, harus ada tindak lanjut yang konkret supaya umat Islam mau mengikuti apa yang difatwakan oleh MUI terkait pembelian pemakaman mewah.

\section{Batasan Penelitian}

Pembahasan mengenai pemakaman mewah dapat dikatakan belum banyak. Penelitian ini akan membatasi pada kemungkinan responden akan membeli pemakaman mewah atau tidak. Selanjutnya akan dikaji faktor apa yang paling berpengaruh dalam pengambilan keputusan tersebut.

\section{KERANGKA TEORI}

\section{Intensi}

Kajian tentang intensi diawali oleh Fishbein dan Ajzen pada tahun 1975 dengan Teori Reasoned Action [14] (Fishbein \& Ajzen, 1975). Dalam perkembangan selanjutnya, kajian intensi dilajutkan sendiri oleh Ajzen. Pada awalnya Fishbein dan Ajzen [14] mendefinisikan intensi sebagai sebuah motivasi yang memiliki dampak pada timbulnya perilaku. Intensi mengindikasikan bahwa seseorang dengan sengaja mencoba dan merencanakan untuk menampilkan suatu perilaku tertentu. Mereka berdua juga menyatakan bahwa intensi merupakan sebuah proses mental yang disadari dan timbul atas kemauan manusia itu sendiri. Intensi tercakup dalam 3 (tiga) ranah yaitu kognisi (merasa dan menerima), konasi (usaha, kemauan, hasrat, keinginan), dan perasaan (mencintai, membenci).

Pada 1988, Ajzen [15] menyatakan bahwa intensi diasumsikan sebagai faktor motivasional yang mempengaruhi perilaku; intensi adalah indikasi seberapa kuat keinginan seseorang untuk mencoba, atau berapa banyak usaha yang direncanakan untuk menampilkan perilaku . Dari beberapa definisi tersebut diatas, maka dapat ditarik kesimpulan bahwa intensi merupakan kemungkinan seseorang untuk memunculkan perilaku tertentu dengan faktor motivasional yang mempengaruhi bagaimana usaha yang digunakan untuk menampilkan perilaku tersebut.

\section{Hal yang Diperhatikan dalam Pengukuran Intensi}

Perilaku manusia adalah hasil dari pemikiran yang dikontrol atas kemauan manusia itu sendiri (volitional control). Dengan kata lain, manusia dapat dengan mudah memunculkan perilaku tertentu jika ia memiliki kecenderungan yang tinggi untuk mewujudkan perilaku itu. Demikian juga sebaliknya, manusia tidak akan memunculkan perilaku tertentu jika ia memutuskan untuk tidak mewujudkan suatu perilaku [15].

Lebih lanjut, intensi adalah motivasi yang terkuat yang dapat mendukung sikap positif seseorang terhadap perilaku tertentu. Intensi merupakan variabel paling dekat dengan munculnya perilaku. Perilaku yang terwujud atas dasar intensi ini disebut dengan perilaku yang diniatkan. Perilaku yang telah diniatkan ini akan terwujud pada waktu dan tempat yang tepat untuk mewujudkan perilaku tersebut. 
Terdapat empat hal yang perlu diperhatikan dalam pengukuran intensi (specificity of intentions). Pengukuran tersebut harus sesuai dengan sasaran pengukuran yang dituju (target), tingkah laku (behavior) yang dilibatkan, situasi (situation) tempat tindakan itu terjadi, dan waktu (time) yang tepat untuk mewujudkan tingkah laku [14]. Keempat elemen ini selalu terlibat dalam setiap pengukuran tingkah laku, baik itu secara verbal ataupun nonverbal. Menurut Fishbein dan Ajzen [14], pengukuran sikap yang terbaik agar dapat memprakirakan perilaku adalah dengan memasukkan sekaligus keempat elemen intensi tersebut diatas, yaitu target, perilaku, konteks, dan waktu.

Pembentukan intensi yang dihasilkan sebelum perubahan perilaku terjadi, tidak dapat diharapkan bahwa pengukuran itu dapat meramalkan perilaku yang tepat. Dengan kata lain, ketepatan dari pengukuran intensi biasanya tidak sesuai apabila telah terjadi campur tangan waktu yang terlalu lama antara pengukuran intensi yang dihasilkan dengan perilaku yang teramati.

\section{Teori Tindakan Berencana (Theory of Planned Behavior)}

Theory of Planned Behavior (TPB) merupakan salah satu teori yang berhubungan dengan sikap [16] . Teori tersebut didahului oleh Theory of Reasoned Action. Ajzen mengungkapkan bahwa sikap sering memengaruhi tingkah laku manusia. Ajzen dan Fishbein [14], dalam [16] mengungkapkan Theory of Reasoned Action yang mengasumsikan bahwa pada umumnya manusia cukup rasional dan menggunakan informasi secara sistematis. Implikasi dari perilaku akan dipertimbangkan sebelum memutuskan akan berperilaku atau tidak. Namun dalam perkembangan selanjutnya, Ajzen menganggap bahwa hubungan antara sikap dan perilaku dalam Theory of Reasoned Action tidak menjelaskan mengenai perilaku yang tidak sepenuhnya dapat dikendalikan oleh orang yang bersangkutan, melainkan juga dipengaruhi oleh faktor non motivasional meski ia memiliki sikap positif terhadap perilaku yang dimaksud. Sehingga, akhirnya Ajzen menambahkan 1 determinan lagi yaitu kendali terhadap perilaku yang dipersepsikan, yaitu persepsi mengenai mudah-sulitnya suatu perilaku dilakukan. Jadi, menurut Theory of Planned Behavior, intensi dipengaruhi oleh tiga hal, yaitu sikap, norma subyektif (seperti pada Theory of Reasoned Action), ditambah kendali perilaku yang dipersepsikan [15] dalam [16]; dan
[17]; [18]. Penjelasan dari determinan tersebut adalah sebagai berikut :

\section{Sikap}

Menurut Ajzen [6], sikap adalah evaluasi individu secara positif atau negatif terhadap benda, orang, institusi, kejadian, perilaku atau minat tertentu. Sikap dipandang sebagai sesuatu yang afektif atau evaluatif. Konsep sentral yang menentukan sikap adalah belief. Berdasarkan teori ini, sikap individu terhadap suatu perilaku diperoleh dari keyakinan terhadap konsekuensi yang ditimbulkan oleh perilaku tersebut, yang diistilahkan dengan behavioral beliefs (keyakinan terhadap perilaku). Keyakinan terhadap perilaku menghubungkan perilaku dengan hasil tertentu, atau beberapa atribut lainnya seperti biaya atau kerugian yang terjadi saat melakukan suatu perilaku. Dengan perkataan lain, seseorang yang yakin bahwa sebuah tingkah laku dapat menghasilkan outcome yang positif, maka individu tersebut akan memiliki sikap yang positif, begitu juga sebaliknya. Objek sikap dalam penelitian ini adalah pemakaman mewah. Jika individu memberikan penilaian (evaluasi) positif terhadap makam mewah, maka akan semakin mungkin individu membeli, dan sebaliknya.

\section{Norma Subjektif}

Norma subjektif merupakan kepercayaan/ persepsi seseorang mengenai persetujuan orang lain terhadap suatu tindakan [15] dalam [16]. Lebih jauh, didefinisikan sebagai adanya persepsi individu terhadap tekanan sosial/orang lain di sekitarnya untuk menunjukkan atau tidak menunjukkan suatu perilaku. Individu memiliki keyakinan bahwa individu lain atau kelompok tertentu akan menerima atau tidak menerima tindakan yang dilakukannya. Orang lain yang dimaksud disebut referent, bisa berupa orang tua, sahabat, atau orang lain yang dianggap ahli/penting misalnya ulama. Ada dua faktor yang memengaruhi norma subjektif: yaitu normative belief (keyakinan individu bahwa referent berpikir ia harus melakukan atau harus tidak melakukan sesuatu perilaku), dan motivation to comply (motivasi individu untuk memenuhi norma dari referent tersebut). Apabila individu meyakini apa yang menjadi norma kelompok, maka individu akan mematuhi dan membentuk perilaku yang sesuai dengan kelompoknya. Dalam riset ini, jika individu menganggap bahwa tidak ada tekanan dari referent terkait pembelian makam mewah, maka akan semakin mungkin individu akan melakukan pembelian, dan sebaliknya. 


\section{Kontrol terhadap Tingkah Laku yang Dipersepsikan}

Kontrol terhadap tingkah laku yang dipersepsikan (perceived behavioral control) merupakan persepsi/keyakinan terhadap mudah/sulitnya sebuah perilaku dapat dilaksanakan; mengenai ada/tidaknya faktor-faktor yang memfasilitasi dan menghalangi individu untuk melakukan suatu perilaku (perceived facilitation). Determinan ini diasumsikan merefleksikan pengalaman masa lalu, dan mengantisipasi halangan yang mungkin akan terjadi. Kendali perilaku ditentukan oleh pengalaman masa lalu individu dan juga perkiraan individu mengenai seberapa sulit atau mudahnya untuk melakukan suatu perilaku (control belief). Pengalaman masa lalu individu terhadap suatu perilaku bisa dipengaruhi oleh informasi yang didapat dari orang lain, misalnya dari pengalaman orang-orang yang dikenal seperti keluarga, pasangan dan teman. Ajzen [15] menjelaskan bahwa perilaku seseorang tidak hanya dikendalikan oleh dirinya sendiri, tetapi juga membutuhkan kontrol, misalnya berupa ketersediaan sumber daya dan kesempatan bahkan keterampilan tertentu. Kontrol perilaku merepresentasikan kepercayaan seseorang tentang seberapa mudah individu menunjukkan suatu perilaku. Ketika individu percaya bahwa dirinya kekurangan sumber atau tidak memiliki kesempatan untuk menunjukkan suatu perilaku (kontrol perilaku yang rendah), individu tidak akan memiliki intensi yang kuat untuk menunjukkan perilaku tersebut [15]. Dalam beberapa situasi, satu atau dua faktor saja dapat digunakan untuk menjelaskan intensi, dan kebanyakan ketiga faktor ini masing-masing berperan dalam menjelaskan intensi. Sebagai tambahan, tiap individu memiliki perbedaan bobot dari antara ketiga faktor tersebut mana yang paling mempengaruhi individu tersebut dalam berperilaku [6]. Dalam riset ini, jika individu menganggap bahwa perilaku membeli akan mudah untuk dilakukan, dan dia pasti mampu maka semakin mungkin baginya untuk membeli makam mewah, dan sebaliknya.

Dengan demikian, dapat disimpulkan bahwa seseorang akan melakukan suatu perilaku tertentu jika :

a) orang tersebut memberikan evaluasi yang positif terhadap suatu perilaku,

b) ditambah dengan individu tersebut mendapatkan tekanan dari lingkungan sosial (refferent) untuk melakukan perilaku tersebut, c) serta individu tersebut percaya (memiliki belief) bahwa dia bisa dan memiliki kesempatan untuk melakukan perilaku tersebut [6] .

Jadi, dalam riset ini, intensi seseorang untuk melakukan pembelian kavling makam mewah dapat diketahui dengan cara mengukur apakah dia memiliki evaluasi yang positif terhadap pembelian tersebut, tidak adanya tekanan dari lingkungan sosial/refferent, dan dia merasa mampu serta memiliki kesempatan untuk membeli makam mewah.

\section{Psikologi Konsumen}

Schiffman dan Kanuk (dalam [19]) menyebutkan bahwa perilaku konsumen adalah proses yang dilalui oleh seseorang dalam mencari, membeli, menggunakan, mengevaluasi, dan bertindak pasca konsumsi produk, jasa maupun ide, yang diharapkan bisa memenuhi kebutuhannya. Dalam arti lain perilaku konsumen merupakan studi tentang bagaimana pembuat keputusan (Decision Units), baik individu, kelompok, ataupun organisasi membuat keputusankeputusan beli atau melakukan transaksi pembelian suatu produk dan mengkonsumsinya. Sedangkan menurut American Marketing Association, perilaku konsumen adalah interaksi yang dinamis antara pengaruh dan kognisi, perilaku, dan kejadian di sekitar kita di mana manusia melakukan Faktor pertukaran dalam hidup mereka (Peter Paul, J. dalam [19] ).

Secara umum, konsumsi dinyatakan sebagai kegiatan atau tindakan mempergunakan komoditas baik yang berupa barang atau jasa untuk memenuhi keinginan (Lipksey, dalam [20]). Jadi, komoditas tidak hanya komoditas berupa barang dan sesuatu yang akan dimakan atau diminum, tetapi juga jasa. Dalam riset ini, komoditas yang dimaksud adalah berupa lahan dan jasa pemakaman, dan proses keputusan individu atau organisasi untuk membeli atau tidak membeli suatu produk barang, jasa dan ide dapat dipengaruhi oleh faktor internal, dan eksternal (lingkungan). Dalam riset ini, proses keputusan yang dimaksud akan ditelusuri lebih dalam dengan menggunakan Teori Tindakan Berencana dari Ajzen.

\section{Psikologi Kematian}

Kematian hanya merupakan salah satu tahap dari perjalanan manusia sebagai makhluk yang diciptakan Allah. Setelah manusia diciptakan dengan sebaik-baiknya bentuk mulai dari masa 
konsepsi, Allah kemudian mematikannya. Namun sesudah itu, manusia akan dibangkitkan di hari kiamat.

Menurut perspektif islam, kematian dianggap sebagai peralihan kehidupan, dari kehidupan dunia menuju kehidupan di alam lain. Menurut islam, setelah meninggal dan dikuburkan, manusia akan dihidupkan kembali. Kematian di alam kubur seperti tidur untuk menghadapi hari kebangkitan. Mereka yang berpisah karena kematian di dunia, dapat bertemu kembali dalam kehidupan setelah mati. Meski begitu, kehidupan setelah mati merupakan hal yang sulit untuk dibuktikan secara empirik. Manusia yang telah mengalami kematian tidak dapat kembali ke dunia untuk memberi tahu apa yang terjadi setelah mati, kecuali bagi manusia yang mengalami mati suri. Penelitian terhadap mereka menunjukan adanya kesamaan pola pengalaman mati suri, dan menunjukkan adanya kemungkinan besar tentang kehidupan setelah mati.

Di sisi lain, psikologi sebagai sebuah ilmu yang mengkaji pikiran, perasaan, dan perilaku seseorang melihat kematian sebagai suatu peristiwa dahsyat yang sesungguhnya sangat berpengaruh dalam kehidupan seseorang. Ada segolongan orang yang memandang kematian sebagai sebuah malapetaka. Namun ada pandangan yang sebaliknya bahwa hidup di dunia hanya sementara, dan ada kehidupan lain yang lebih mulia kelak, yaitu kehidupan di akhirat. Terkait hal itu, maka apa yang dimiliki di dunia, termasuk kekayaan, menjadi tidak ada artinya karena yang lebih penting adalah bekal kekayaan sesudah mati.

Pandangan tersebut melahirkan dua mazhab psikologi kematian. Pertama, mazhab sekuler yang tidak peduli dan tidak yakin adanya kehidupan setelah mati. Kedua, mazhab religius, yaitu yang memandang bahwa keabadian setelah mati itu ada. Kehidupan di dunia perlu dinikmati, tetapi bukan tujuan akhir dari kehidupan. Apa saja yang dilakukan di dunia dimaksudkan untuk investasi kejayaan di akhirat [21].

Dalam perspektif Agama Islam, Kematian dinilai secara positif, sebagai suatu proses yang mau tidak mau akan dijalani oleh setiap yang bernyawa, termasuk manusia. Allah SWT dalam FirmanNYA menyatakan bahwa setiap yang bernyawa pasti akan merasakan mati. Kehidupan dan kematian adalah salah satu dari tanda-tanda kebesaran Allah. Kehidupan dan kematian adalah ujian bagi manusia, agar manusia dapat mengambil pelajaran dari keduanya, dan berbuat baik di atas bumi, seperti yang tercantum dalam Al Quran, Surat AlMulk: 2 :

(Dialah Allah) yang menjadikan mati dan hidup, supaya Dia menguji kalian, siapa diantara kalian yang baik amalnya. Di dalam arti ayat tersebut menyiratkan bahwa yang lebih dilihat oleh Allah SWT adalah manusia yang baik amalnya, bukan yang banyak hartanya.

\section{Pemakaman Mewah}

Berdasar riset sebelumnya, Firmiana dkk [5] menuliskan bahwa pemakaman mewah adalah kompleks pemakaman yang disediakan oleh pemberi jasa non pemerintah. Jika TPU yang disediakan pemerintah memiliki tarif yang ditetapkan oleh pemerintah, maka di pemakaman mewah tarif atau harga yang tinggi sepadan dengan layanan yang disiapkan dan diberikan oleh penyedia jasa, dalam hal ini pengembang. Kompleks pemakaman mahal dan mewah ini dibangun dengan indah, sehingga menghindari kesan seram yang selama ini melekat pada kompleks pemakaman [7], [22], dalam [5]. Dengan harga ini, berbagai macam fasilitas dan layanan berkelas disediakan oleh pengelola, seperti rumah ibadah dari semua agama yang diakui negara yang masuk kategori bagus dan megah, hotel, restoran Italia, kolam renang, dan danau buatan. Selain itu pemakaman ini juga berada di lokasi yang berbukit dan hijau, sangat menyenangkan untuk berjalan kaki, jogging (tersedia jogging track), dan bersepeda.

Keistimewaan yang lain adalah pengelola menawarkan hanya membayar sekali seumur hidup (artinya setelah melunasi semua pembayaran maka pelanggan digratiskan dari biaya perawatan selamanya, sehingga tidak ada beban untuk ahli waris), juga lokasi makam yang bagus dan boleh dipilih (disesuaikan dengan dana yang dimiliki oleh calon pembeli). Pemilihan lokasi ini misalnya bagi etnis Tionghoa, yang memiliki kepercayaan bahwa semakin tinggi lokasi makam (ke arah perbukitan) semakin menunjukkan status sosial, berarti semakin bagus. Konsekuensinya adalah harga akan semakin mahal.

Pengelola juga memberikan layanan penyelenggaraan jenazah sesuai dengan agama yang dianut. Misalnya untuk yang Muslim, disediakan layanan mulai dari mengurus sejak diketahui meninggal, memandikan, mengafani, menyalatkan, sampai seremonial di tempat pemakaman (pengelola menyediakan ustadz, dan 
pembaca doa). Untuk pelanggan selain muslim, yang memilih nantinya ingin dikremasi, telah disediakan berbagai pilihan guci ataupun kotak tempat abu kremasi. Selanjutnya, tempat peletakan guci atau kotak juga dipilih sendiri, sesuai dengan dana yang dimiliki.

Pilihan cara pembelian kavling makam pun disediakan oleh pengelola. Ada yang bisa dipersiapkan sebelumnya oleh pelanggan semasa hidup, sehingga saat meninggal nanti tidak merepotkan pihak keluarga karena segala sesuatunya sudah diurus oleh pihak pengelola. Namun ada juga kavling makam yang baru dibeli oleh keluarga ketika ada anggotanya yang meninggal. Layanan penyelenggaraan jenazah yang diberikan oleh pengelola tetap sama, kecuali pihak keluarga menginginkan mengurus sendiri penyelenggaraan jenazah dan pemakaman [5].

\section{Kajian Riset Sebelumnya}

Riset mengenai intensi relatif banyak ditemukan, misalnya Puspitasari [23] yang meneliti intensi kasus bullying non fisik pada remaja yang menonton sinetron "Diam-diam Suka". Selain itu juga ada intensi menggunakan TransJakarta untuk pergi ke tempat kerja [24] ; juga prediksi intensi mahasiswa untuk bersepeda di kampus [25]. Semua riset ini menggunakan teori Intensi dari Ajzen. Pada penelitian Puspitasari [23], kontrol terhadap perilaku yang dipersepsikan memiliki pengaruh yang signifikan terhadap intensi melakukan bullying non fisik. Pada penelitian Mulya [24], norma subjektif memiliki peran lebih besar pada intensi menggunakan transJakarta ke tempat kerja. Sedangkan pada Amaliah [25], faktor yang paling berperan pada intensi adalah sikap terhadap bersepeda di kampus.

Jika riset terkait intensi relatif banyak, namun tidak demikian halnya dengan riset tentang pemakaman mewah. Setelah melakukan pencarian pada jurnal dalam dan luar negeri, belum ditemukan artikel ilmiah dengan tema tersebut. Riset bertema sama yang ditemukan hanya pada nama tim peneliti yang sama, yang mengkaji pengaruh status sosial ekonomi terhadap persepsi mengenai trend pemakaman mewah. Di dalam riset tersebut ditemukan bahwa status sosial ekonomi berpengaruh terhadap persepsi, dan dimensi yang paling berpengaruh adalah pekerjaan (Firmiana, dkk [5]). Terkait hasil tersebut, tim akan melanjutkan penelitian dengan mencoba memprediksi kemungkinan masyarakat untuk membeli makam mewah.

\section{METODE PENELITIAN}

\section{Metode}

Penelitian ini akan menggunakan metode kuantitatif, yang merupakan sebuah penelitian yang menggunakan sejumlah pengukuran numerik terkait fenomena yang sedang diteliti [26] .

\section{Teknik Pengumpulan dan Analisa Data}

Pengumpulan data dalam penelitian ini menggunakan kuesioner. Kuesioner merupakan daftar pertanyaan yang digunakan untuk memperoleh keterangan dari sampel atau sumber yang beraneka ragam yang lokasinya sering tersebar di daerah yang luas. Pada umumnya kuesioner meminta keterangan tentang fakta yang diketahui oleh responden [27]. Pada penelitian ini, tim akan menyusun kuesioner seperti panduan yang ada di [18], website resmi Ajzen.

\section{Sumber Data}

Data awal dalam rencana penelitian ini adalah hasil riset sebelumnya [5]. Selain itu tim peneliti juga melakukan wawancara awal dengan sejumlah anggota masyarakat yang ditemui secara accidental di beberapa tempat. Hasil yang diperoleh adalah ditemukan pendapat yang beragam. Sebagian individu menunjukkan sejalan dengan riset [5], yaitu menganggap tidak perlu dan tidak akan membeli; sementara sebagian lagi berpendapat sebaliknya. Pertimbangan mereka adalah tidak ingin merepotkan keluarga saat dirinya meninggal, juga dalam hal perawatan makamnya. Data awal berikutnya adalah mengenai biaya. Menurut sejumlah informan yang diwawancarai, biaya yang mahal bukanlah sesuatu hal yang akan menjadi masalah, karena biaya tersebut dapat diusahakan dengan bekerja keras mulai dari sekarang. Bahkan sebagian dari informan yang berniat menyiapkan makam mewah untuk diri sendiri, juga sekaligus akan menyiapkan untuk pasangan, orang tua, saudara, serta anak-anaknya sekaligus. Data berikutnya adalah data yang akan dikumpulkan melalui kuesioner untuk dianalis dengan SPSS for windows.

Sementara data utama adalah data bersumber dari responden yang merupakan anggota majlis taklim. Metode pemilihan responden adalah accidental, yaitu siapapun anggota majelis taklim yang ditemui dan berkenan mengisi kuesioner. Rentang usia juga tidak dibatasi. 


\section{HASIL DAN PEMBAHASAN}

\section{Deskripsi Umum Responden Penelitian}

Responden dalam penelitian ini berjumlah 80 (delapan puluh) orang. Karena bersifat accidental, maka jumlah responden yang diperoleh tidak banyak. Deskripsi usia responden penelitian seperti tabel di bawah ini:

Tabel 1.

Gambaran Umum Responden Berdasarkan Usia

\begin{tabular}{ccc}
\hline Usia & Frekuensi & Persentase (\%) \\
\hline $\mathbf{2 1 - 3 0}$ & 13 & $16.25 \%$ \\
\hline $\mathbf{3 1 - 4 0}$ & 39 & $48.75 \%$ \\
\hline $\mathbf{> 4 1}$ & 28 & $35 \%$ \\
\hline TOTAL & $\mathbf{8 0}$ & $\mathbf{1 0 0 \%}$ \\
\hline
\end{tabular}

Berdasarkan tabel tersebut terlihat bahwa frekuensi terbesar berada di rentang usia 31-40 tahun, dan menyusul rentang usia di atas 41 tahun.

\section{Pengaruh 3 (tiga) Faktor Intensi terhadap Tingkah laku Membeli Pemakaman Mewah}

Analisis data pada pengujian hipotesis penelitian ini menggunakan metode analisis regresi linier berganda yang akan menjelaskan pengaruh sikap, norma subjektif, dan 76 kontrol perilaku yang dipersepsikan terhadap intensi membeli pemakaman mewah, dengan bantuan program SPSS 21.0 for windows. Variabel bebas (IV) dimasukkan sebagai variabel prediktor dengan tidak memandang apakah pengaruh variabel tersebut besar atau kecil terhadap variabel terikat (DV). Hasilnya dapat dilihat berdasarkan tabel-tabel 2 di lampiran.

Dari tabel Model Summary di Tabel 2 tersebut dapat dilihat bahwa perolehan R Square (yang juga disebut koefisien determinasi) adalah 0.676, artinya semua faktor yang dijelaskan oleh IV memiliki pengaruh sebesar $67.6 \%$ terhadap DV, dan sisanya dipengaruhi oleh faktor lain. Dengan kata lain, faktor sikap, norma subjektif, dan kontrol terhadap tingkah laku yang dipersepsikan memiliki pengaruh sebesar $67.6 \%$ pada tingkah laku membeli pemakaman mewah.

Sementara itu penghitungan ANOVA di Tabel 3 yang dapat dilihat di lampiran menunjukkan model regresi berganda, yang menggunakan sig $<0.05$. Berdasarkan tabel tersebut dapat diketahui bahwa harga $F_{\text {hitung }}=52.879$. Selanjutnya nilai $F_{\text {hitung }}$ dibandingkan dengan $\mathrm{F}_{\text {tabel }}$. Karena $\mathrm{F}_{\text {hitung }}>\mathrm{F}_{\text {tabel, }}$ maka persamaan regresi yang diperoleh dapat digunakan untuk menjelaskan dan mengambil kesimpulan lebih lanjut mengenai pengaruh faktor faktor intensi terhadap tingkah laku membeli makam mewah. Selain itu, berdasarkan nilai signifikansi yang terdapat dalam tabel yaitu $0.000<0.05$ ini berarti ada pengaruh yang signifikan antara faktor-faktor intensi masyarakat (IV) terhadap tingkah laku membeli makam mewah (DV). Lebih lanjut dapat dijelaskan bahwa faktor sikap, norma subjektif, dan kontrol terhadap tingkah laku yang dipersepsikan secara bersamasama memiliki pengaruh signifikan terhadap tingkah laku membeli makam mewah.

Selanjutnya akan dilakukan analisis pengaruh pada setiap faktor pembentuk IV terhadap tingkah laku membeli pemakaman mewah.

\section{Pengaruh Faktor Sikap Terhadap Tingkah Laku Membeli Pemakaman Mewah}

Berdasarkan Tabel 4 (di lampiran) dapat dilihat bahwa $\mathrm{R}$ square untuk faktor sikap terhadap pemakaman mewah adalah $30,4 \%$. Hal ini berarti sikap terhadap pemakaman mewah berpengaruh sebesar 30, 4\% terhadap tingkah laku membeli. Sementara berdasar penghitungan ANOVA yang dapat dilihat di lampiran diperoleh $\mathrm{F}_{\text {hitung }}$ sebesar $34,10 \%$, sementara $F_{\text {tabel }}$ adalah 3.964. Karena $F_{\text {hitung }}>F_{\text {tabel, }}$ ini berarti bahwa faktor sikap memiliki pengaruh yang signifikan sebesar 34,10\% terhadap tingkah laku membeli pemakaman mewah.

Berdasarkan dua tabel tersebut, dapat dijelaskan bahwa evaluasi terhadap pemakaman mewah yang berharga tinggi akan mempengaruhi kemungkinan responden untuk melakukan pembelian atau tidak. Penilaian bahwa makam mewah pasti mahal, elegan, asri, indah, terawat rapi, prestisius, dan hanya dimiliki oleh orang terkenal dan penting dapat mempengaruhi responden untuk melakukan pembelian. Jika evaluasinya positif, maka dia akan melakukan pembelian, dan sebaliknya. Dalam riset ini, penilaian positif atau negatif tidak dikaji lebih jauh; namun mengkaji seberapa besar pengaruh faktor evaluasi tersebut yaitu $34,10 \%$, yang berarti sangat signifikan.

\section{Pengaruh Faktor Norma Subjektif Terhadap tingkah laku Membeli Pemakaman Mewah Untuk pengujian ini, data dilihat dari Tabel 5, Uji F Faktor Norma Subjektif, di lampiran. Tabel tersebut menunjukkan bahwa $\mathrm{R}$ square Faktor Norma Subjektif memiliki pengaruh sebesar $51.1 \%$ terhadap tingkah laku membeli pemakaman}


mewah. Sementara pada penghitungan ANOVA terlihat bahwa nilai $\mathrm{F}_{\text {hitung }}$ adalah 81.578 , dan $\mathrm{F}_{\text {tabel }}$ 3.964. Karena $F_{\text {hitung }}>F_{\text {tabel, }}$ berarti bahwa Faktor norma subjektif memiliki pengaruh yang signifikan terhadap tingkah laku membeli pemakaman mewah.

Berdasarkan tabel tersebut, dapat dijelaskan bahwa faktor norma subjektif berpengaruh signifikan, dengan besaran $51.1 \%$. Jadi dapat dijelaskan juga bahwa kepercayaan/persepsi mengenai persetujuan orang lain terhadap suatu tindakannya akan berpengaruh sebesar $51.1 \%$ pada kemungkinan responden untuk melakukan pembelian makam mewah. Jadi, tingkah laku membeli pemakaman mewah dipengaruhi oleh persepsi responden terhadap tekanan sosial/orang lain di sekitarnya ketika dia menunjukkan menunjukkan tingkah laku tersebut. Responden memiliki keyakinan bahwa individu lain atau kelompok tertentu bisa saja menerima atau tidak menerima tingkah lakunya membeli pemakaman mewah. Orang lain yang dimaksud disebut referent, bisa berupa orang tua, sahabat, atau orang lain yang dianggap ahli/penting misalnya ulama. Jika individu menganggap bahwa tidak ada tekanan dari referent terkait pembelian makam mewah, maka akan semakin mungkin individu untuk melakukan pembelian, dan sebaliknya.

\section{Pengaruh Faktor "Kontrol terhadap Tingkah Laku yang Dipersepsikan" terhadap Tingkah Laku Membeli Pemakaman Mewah}

Untuk menguji ini, dapat dilihat dari tabel Tabel 6 di lampiran. Tabel terebut menunjukkan bahwa $\mathrm{R}$ square dari Faktor "Kontrol terhadap Tingkah Laku yang Dipersepsikan" memiliki pengaruh sebesar $54.5 \%$ terhadap tingkah laku membeli pemakaman mewah. Sedangkan penghitungan Anova menunjukkan $\mathrm{F}_{\text {hitung }}$ adalah 93.307, dan $\mathrm{F}_{\text {tabel }}$ 3.964. Karena $F_{\text {hitung }}>F_{\text {tabel, }}$ berarti bahwa Faktor kontrol terhadap tingkah laku yang dipersepsikan memiliki pengaruh yang signifikan pada tingkah laku membeli pemakaman mewah.

Kedua tabel sebelumnya memberikan informasi bahwa faktor "kontrol terhadap tingkah laku yang dipersepsikan" memiliki pengaruh yang signifikan, dengan besaran angka 54.5\%. Dalam riset ini, kontrol terhadap tingkah laku yang dipersepsikan adalah persepsi/keyakinan responden terhadap mudah/sulitnya perilaku membeli pemakaman mewah dapat dilaksanakan; dan mengenai ada/tidaknya faktor-faktor yang memfasilitasi dan menghalangi individu untuk melakukan perilaku membeli pemakaman mewah. Lebih lanjut dapat dijelaskan bahwa jika responden memiliki persepsi /keyakinan bahwa perilaku membeli pemakaman mewah merupakan sesuatu yang mudah untuk dilakukan, maka tingkah laku membeli pemakaman mewah akan semakin mungkin dilakukan, dan sebaliknya. Jika responden percaya bahwa dirinya kekurangan sumber atau tidak memiliki kesempatan untuk menunjukkan perilaku membeli pemakaman mewah, responden tidak akan memiliki intensi yang kuat untuk menunjukkan perilaku tersebut (Ajzen, 1988).

Kendali perilaku ditentukan oleh pengalaman masa lalu individu dan juga perkiraan individu mengenai seberapa sulit atau mudahnya untuk melakukan suatu perilaku (control belief). Pengalaman masa lalu individu terhadap suatu perilaku bisa dipengaruhi oleh informasi yang didapat dari orang lain, misalnya dari pengalaman orang-orang yang dikenal seperti keluarga, pasangan dan teman.

\section{PENUTUP}

\section{Kesimpulan}

Berdasarkan pembahasan pada bab sebelumnya maka dapat ditarik kesimpulan sebagai berikut ;

1. aspek sikap, norma subjektif, dan kontrol terhadap perilaku yang dipersepsikan secara bersama-sama memiliki pengaruh terhadap tingkah laku membeli pemakaman mewah.

2. Hal ini berarti bahwa keputusan untuk membeli pemakaman mewah, dipengaruhi oleh evaluasi individu terhadap pemakaman mewah, kepercayaan / persepsi individu mengenai persetujuan orang lain terhadap tingkah lakunya membeli pemakaman mewah, dan persepsi/keyakinan terhadap mudah/sulitnya untuk melakukan tingkah laku membeli pemakaman mewah.

3. jika diteliti per faktor, maka faktor yang paling berpengaruh adalah kontrol terhadap tingkah laku yang dipersepsikan. Pembelian yang akan dilakukan, dipengaruhi oleh persepsi/keyakinan terhadap mudah/sulitnya untuk melakukan tingkah laku membeli pemakaman mewah. Dengan demikian dapat disimpulkan juga bahwa persepsi terhadap mahalnya pemakaman mewah merupakan faktor yang paling berpengaruh.

\section{Saran}

Berdasarkan temuan, pembahasan dan kesimpulan yang sudah dipaparkan sebelumnya, maka tim peneliti memberikan saran sebagai berikut : 
1. Bagi MUI, riset ini dapat dijadikan salah satu pertimbangan untuk fatwa mengenai pemakaman mewah yang sebelumnya disebutkan termasuk kategori haram karena dinilai berlebihan.

2. Bagi penelitian selanjutnya, diharapkan dapat melakukan pengujian dengan jumlah responden yang lebih besar, dan cakupan area yang lebih luas, untuk dapat memperoleh penjelasan terhadap fenomena ini dengan lebih baik.

3. Bagi developer, layak untuk menurunkan harga atau promo-promo menarik sehingga produk mereka dapat terjual dengan lebih cepat.

Dalam riset ini, peneliti tidak membagi referent yang dimaksud di norma subjektif. Peneliti tidak meneliti referent mana yang paling berpengaruh. Jika data ini dapat diperoleh, maka pihak developer dapat menyusun rencana pemasaran sesuai referent tersebut.

\section{DAFTAR PUSTAKA}

[1] www.detik.com. (Diakses pada 28 September 2014).

[2] www.jakarta.go.id. (Diakses pada 30 April 2014).

[3] www.hukumonline.com. (Diakses pada 30 April 2014).

[4] www.bps.go.id. (Diakses pada 30 April 2014).

[5] M. E. Firmiana, R. Imawati and S. Rahmawati, . 2014. "Hubungan SSE dengan Persepsi Masyarakat terhadap Trend Pemakaman Muslim yang Mahal". Seminar hasil Laporan Grant LP2M Universitas Al Azhar Indonesia, Jakarta, 2014.

[6] I. Ajzen, Attitude, Personality, and Behavior; Second Edition., Milton Keynes: Open University Press, 2005.

[7] www.antara news.com. (Diakses pada 30 April 2014].

[8] http://www.al-azhar.ac.id. (Diakses pada 30 April 2014).

[9] http://www.berita-bisnis.com/data-bisnis/345bisnis-pemakaman-makin-diminati.html. (Diakses pada 2012).

[10] http://www.kabar6.com/tangerangraya/kabupaten-tangerang/506-pembangunansan-diego-hills-tangerang-dipercepat.html. (Diakses pada 2012).

[11] http://mui.or.id/wpcontent/uploads/2014/05/No.-09-Jual-Beli-
Tanah-utk-Kuburan-dan-Bisnis-LahanKuburan-Mewah.pdf. (Diakses pada 30 April 2014).

[12] http://sales-sandiegohills.com/kuburanislam/fitrah-mansion-san-diego-hills/.

(Diakses pada 28 September 2014).

[13] I. Salehudin and B. Luthfi, "Marketing Impact of Halal Labelling toward Indonesian Muslim Consumers Behaviour Intention Theory : Policy Capturing Studies on Five Different Product Categories," in 5 th International Conference on Business and Management Research (ICBMR), Depok, Indonesia, 2010.

[14] M. S. \&. A. I. Fishbein, Beliefs, Attitude, Intention, and Behavior., Massachussets: Wesley Publishing Company, 1975.

[15] I. Ajzen, Attitude, Personality, and Behavior., Milton Keynes: Open University Press, 1988.

[16] R. A. Baron, D. Byrne and N. Branscombe, . Social Psychology Eleventh Edition, Boston: Pearson, 2006.

[17] S. W. Sarwono, E. A. Meinarno and (ed), Psikologi Sosial, Jakarta: Penerbit Salemba Humanika, 2009.

[18] http://people.umass.edu/aizen/tpb.html.

[19] A. M. Laksmi, "Pengaruh Konformitas Teman Sebaya terhadap Perilaku Konsumtif pada Kepemilikan Gadget Jenis SmartPhone di Kalangan Remaja di Jakarta Selatan, Skripsi Universitas Al Azhar Indonesia," Universitas Al Azhar Indonesia, Jakarta, 2013.

[20] E. Siswoyo and M. Malo, Sosiologi Konsumsi., Jakarta: Universitas Terbuka Press, 1999.

[21] K. Hidayat, Psikologi Kematian, Mengubah Ketakutan Menjadi Optimisme, Bandung: Noura Books (Mizan Publika), 2012.

[22] www.al-azhar.ac.id. (Diakses pada 30 April 2014).

[23] R. A. Puspitasari, "Pengaruh Sikap, Norma Subjektif, dan Kontrol Perilaku yang Dipersepsikan terhadap Intensi Perilaku Bullying non fisik pada Remaja (Studi Kasus pada Siswa SMP ABC di Jakarta Selatan yang Menonton Sinetron "Diam Diam Suka")," Universitas Al Azhar Indonesia, Jakarta, 2014.

[24] T. Mulya, ". Pengaruh Sikap, Norma Subjektif, dan Perceived Behavioral Control terhadap Intensi Menggunakan TransJakarta untuk Pergi ke Tempat Kerja.," Universitas Indonesia, Depok, 2009. 
[25] K. Amaliah, "Peranan Sikap, Norma Subjektif, dan Perceived Behavioral Control dalam Memprediksi Intensi Mahasiswa untuk Bersepeda di Kampus," Universitas Indonesia, Depok, 2008.

[26] S. Vanderstoep and D. Johnston, Research Methodes for Every Day Life. Blending Qualitative and Quantitatif Approaches, San Fransisco: Jossey Bass, 2009.

[27] S. Nasution, 2000. Metode Research (Penelitian Ilmiah), Jakarta: Bumi Aksara, 2000. 


\section{LAMPIRAN}

Tabel 2. R Square

Descriptive Statistics

\begin{tabular}{|l|r|r|r|}
\hline & \multicolumn{1}{|c|}{ Mean } & Std. Deviation & \multicolumn{1}{|c|}{ N } \\
\hline Tingkah laku_Membeli & 64.81 & 4.381 & 80 \\
Sikap & 19.25 & 2.319 & 80 \\
Norma_Subjektif & 22.25 & 2.703 & 80 \\
Kendali_Perilaku & 36.28 & 4.041 & 80 \\
\hline
\end{tabular}

Model Summary

\begin{tabular}{|c|c|c|c|c|c|c|c|c|c|c|}
\hline \multirow[b]{2}{*}{ Model } & \multirow[b]{2}{*}{$\mathrm{R}$} & \multirow[b]{2}{*}{ R Square } & \multirow[b]{2}{*}{$\begin{array}{c}\text { Adjusted R } \\
\text { Square }\end{array}$} & \multirow[b]{2}{*}{$\begin{array}{l}\text { Std. Error of } \\
\text { the Estimate }\end{array}$} & \multicolumn{5}{|c|}{ Change Statistics } & \multirow{2}{*}{\begin{tabular}{|c} 
Durbi \\
$n-$ \\
Wats \\
on
\end{tabular}} \\
\hline & & & & & $\begin{array}{c}\text { R Square } \\
\text { Change }\end{array}$ & F Change & df1 & $\mathrm{df} 2$ & $\begin{array}{l}\text { Sig. F } \\
\text { Change }\end{array}$ & \\
\hline 1 & $.822^{2}$ & .676 & .663 & 2.542 & .676 & 52.879 & 3 & 76 & .000 & 2.36 \\
\hline
\end{tabular}

a. Predictors: (Constant), Kendali_Perilaku, Sikap, Norma_Subjektif

b. Dependent Variable: perilaku Membeli

Tabel 3. UJI F

ANOVA $^{\text {b }}$

\begin{tabular}{|ll|r|r|r|r|r|}
\hline Model & & Sum of Squares & df & Mean Square & F & Sig. \\
\hline 1 & Regression & 1025.088 & 3 & 341.696 & 52.879 & $.000^{\mathrm{a}}$ \\
& Residual & 491.099 & 76 & 6.462 & & \\
& Total & 1516.188 & 79 & & & \\
\hline
\end{tabular}

a. Predictors: (Constant), Kontrol_Perilaku, Sikap, Norma_Subjektif

b. Dependent Variable: Tngkahlaku_Membeli

Tabel 4. Uji F Faktor Sikap

Model Summary

\begin{tabular}{|c|c|c|c|c|c|c|c|c|c|c|}
\hline \multirow[b]{2}{*}{$\begin{array}{l}\text { Mode } \\
\mid\end{array}$} & \multirow[b]{2}{*}{$\mathrm{R}$} & \multirow[b]{2}{*}{ R Square } & \multirow[b]{2}{*}{$\begin{array}{l}\text { Adjusted } \\
\text { R Square }\end{array}$} & \multirow[b]{2}{*}{$\begin{array}{l}\text { Std. Error of } \\
\text { the Estimate }\end{array}$} & \multicolumn{5}{|c|}{ Change Statistics } & \multirow[b]{2}{*}{$\begin{array}{l}\text { Durbin- } \\
\text { Watson }\end{array}$} \\
\hline & & & & & $\begin{array}{c}\text { R } \\
\text { Square } \\
\text { Change }\end{array}$ & F Change & df1 & $\mathrm{df} 2$ & $\begin{array}{c}\text { Sig. F } \\
\text { Change }\end{array}$ & \\
\hline 1 & $.552^{\mathrm{a}}$ & .304 & .295 & 3.678 & .304 & 34.103 & 1 & 78 & .000 & 1.850 \\
\hline
\end{tabular}

a. Predictors: (Constant), Sikap

b. Dependent Variable : tingkah laku_Membeli

ANOVA $^{\mathrm{D}}$

\begin{tabular}{|ll|r|r|r|r|r|}
\hline Model & Sum of Squares & Df & Mean Square & F & Sig. \\
\hline 1 & Regression & 461.241 & 1 & 461.241 & 34.103 & $.000^{\mathrm{a}}$ \\
& Residual & 1054.946 & 78 & 13.525 & & \\
& Total & 1516.188 & 79 & & & \\
\hline
\end{tabular}

a. Predictors: (Constant), Sikap

b. Dependent Variable: tingkah laku_Membeli 
Tabel 5. Uji F Faktor Norma Subjektif

\section{Model Summary}

\begin{tabular}{|c|c|c|c|c|c|c|c|c|c|c|}
\hline \multirow[b]{2}{*}{ Model } & \multirow[b]{2}{*}{$\mathrm{R}$} & \multirow[b]{2}{*}{ R Square } & \multirow[b]{2}{*}{$\begin{array}{l}\text { Adjusted R } \\
\text { Square }\end{array}$} & \multirow[b]{2}{*}{$\begin{array}{c}\text { Std. Error of } \\
\text { the } \\
\text { Estimate }\end{array}$} & \multicolumn{5}{|c|}{ Change Statistics } & \multirow{2}{*}{$\begin{array}{c}\text { Durbi } \\
\text { n- } \\
\text { Wats } \\
\text { on }\end{array}$} \\
\hline & & & & & $\begin{array}{l}\text { R Square } \\
\text { Change }\end{array}$ & F Change & df1 & $\mathrm{df2}$ & $\begin{array}{c}\text { Sig. F } \\
\text { Chang } \\
\mathrm{e}\end{array}$ & \\
\hline 1 & $.715^{\circ}$ & .511 & .505 & 3.082 & .511 & 81.578 & 1 & 78 & .000 & 2.364 \\
\hline
\end{tabular}

a. Predictors: (Constant), Norma_Subjektif

b. Dependent Variable: tingkah laku_Membeli

\section{ANOVA $^{\mathrm{b}}$}

\begin{tabular}{|c|c|c|c|c|c|c|}
\hline & odel & Sum of Squares & $\mathrm{df}$ & Mean Square & $F$ & Sig. \\
\hline 1 & $\begin{array}{c}\text { Regression } \\
\text { Residual } \\
\text { Total }\end{array}$ & $\begin{array}{c}775.089 \\
741.098 \\
1516.188\end{array}$ & $\begin{array}{c}1 \\
78 \\
79\end{array}$ & $\begin{array}{c}775.089 \\
9.501\end{array}$ & 81.578 & $.000^{\mathrm{a}}$ \\
\hline
\end{tabular}

a. Predictors: (Constant), Norma_Subjektif

b. Dependent Variable: tingkah laku_Membeli

Tabel 6. Uji F faktor Kontrol terhadap Tingkah Laku yang Dipersepsikan

\begin{tabular}{|c|c|c|c|c|c|c|c|c|c|c|}
\hline \multicolumn{11}{|c|}{ Model Summary ${ }^{\mathrm{D}}$} \\
\hline \multirow[b]{2}{*}{ Mode } & \multirow[b]{2}{*}{$\mathrm{R}$} & \multirow[b]{2}{*}{ R Square } & \multirow[b]{2}{*}{$\begin{array}{c}\text { Adjusted R } \\
\text { Square }\end{array}$} & \multirow[b]{2}{*}{$\begin{array}{l}\text { Std. Error } \\
\text { of the } \\
\text { Estimate }\end{array}$} & \multicolumn{5}{|c|}{ Change Statistics } & \multirow[b]{2}{*}{$\begin{array}{l}\text { Durbin- } \\
\text { Watson }\end{array}$} \\
\hline & & & & & $\begin{array}{c}\text { R Square } \\
\text { Change }\end{array}$ & F Change & $\mathrm{df1}$ & $\mathrm{df} 2$ & \begin{tabular}{|c|} 
Sig. F \\
Chang \\
$\mathrm{e}$
\end{tabular} & \\
\hline 1 & $.738^{\mathrm{a}}$ & .545 & .539 & 2.975 & .545 & 93.307 & 1 & 78 & .000 & 2.303 \\
\hline
\end{tabular}

a. Predictors: (Constant), Kendali_Perilaku

b. Dependent Variable: tingkah laku_Membeli

ANOVA $^{\mathrm{D}}$

\begin{tabular}{|ll|r|r|r|r|r|}
\hline Model & Sum of Squares & df & Mean Square & F & Sig. \\
\hline 1 & Regression & 825.832 & 1 & 825.832 & 93.307 & $.000^{\text {a }}$ \\
& Residual & 690.355 & 78 & 8.851 & & \\
& Total & 1516.188 & 79 & & & \\
\end{tabular}

a. Predictors: (Constant), Kendali_Perilaku

b. Dependent Variable: tingkah laku_Membeli 